\title{
Studi Populasi Mikrob Fungsional pada Tanah Gambut yang Diaplikasikan Dua Jenis Pestisida
}

\author{
Study of Funtional Microbes Population in Peat Soil \\ Treated with Two Pesticides
}

\author{
MAIPA DIA PATI ${ }^{*}$, SYAIFUL ANWAR ${ }^{1}$, RAHAYU WIDYASTUTI ${ }^{1}$, DADANG ${ }^{1}$ \\ Departemen Ilmu Tanah dan Sumberdaya Lahan, Fakultas Pertanian, Institut Pertanian Bogor, \\ Kampus Darmaga, Bogor 16680, Indonesia
}

Diterima 13 April 2016/Disetujui 13 Juni 2016

\begin{abstract}
Agricultural land expansion necessity for food security in Indonesia has been faced by the fact in utilizing marginal land such as shallow peat soil in Central Kalimantan. Among problems encountered in such marginal land are pests and diseases incidence. Farmers practice in dealing with those problems is the chemical pesticides application. Unintended chemical pesticides that fall on/into the soil might have an adverse effect to soil microbes activity. This research aimed to assess the effect of pesticides on functional soil microbes population in peat soil. The research used completely randomized factorial design with two factors. First factor was 7 combinations of types (paraquat and buthylphenylmethyl carbamat (BPMC)) and dosages (50, 100, and $200 \%$ of recommended dosage) of pesticides. Second factor was 4 incubation times $(1,7,14$, and 28 days). Following the each of incubation times, the soil samples treated and analyzed for population of phosphate solubilizing microbes, cellulolytic microbes, and $\mathbf{N}_{2}$ fixing bacteria. The results show that phosphate solubilizing fungi population decrease by pesticides treatment. In contrast, pesticides significantly increased the Azospirillum population. Adverse effect to microbes population was found on the first day of incubation, however it recovered at 7 days and longer incubation times. In general, functional microbes population with paraquat application lower than BPMC application.
\end{abstract}

Key words: Peat land, functional microbes, paraquat, buthylphenylmethyle carbamate

\section{PENDAHULUAN}

Upaya pemenuhan ketahanan pangan di Indonesia telah dihadapkan pada ekstensifikasi pertanian dengan memanfaatkan lahan suboptimal, salah satunya adalah lahan gambut. Indonesia adalah negara keempat yang mempunyai lahan gambut terluas di dunia, tetapi pemanfaatan dan pengembangannya masih sangat terbatas. Di beberapa kawasan Asia (termasuk Indonesia) lahan gambut umumnya dimanfaatkan sebagai lahan pertanian (Noor 2001), contohnya penggunaan gambut dangkal sebagai lahan persawahan di daerah Kalimantan Tengah. Berdasarkan data Balai Besar Penelitian dan Pengembangan Sumber Daya Lahan Pertanian (2008) luas lahan gambut di Indonesia diperkirakan sekitar 18 juta ha yang tersebar di beberapa kepulauan dan

*Penulis korespondensi. Phone: +6282312031793 , E-mail: maipadiapati.misdjan@gmail.com
$33 \%$ diantaranya berpotensi untuk digunakan sebagai lahan pertanian. Kalimantan Tengah memiliki luas lahan gambut yang layak untuk pertanian seluas 672.723 ha (BBSDLP 2008).

Pertanian pada lahan gambut dihadapkan pada beberapa permasalahan, salah satunya yaitu tingginya tingkat jangkitan hama dan penyakit terhadap tanaman (Noor 2001). Upaya untuk mengendalikan hama dan penyakit tanaman dalam sistem pertanian intensif seringkali diaplikasikan bahan agrokimia agar bisa mencapai produksi maksimum (Handayanto 2007). Penanganan serangan organisme pengganggu tanaman (OPT) secara kimia, sebagaimana juga dilakukan oleh petani di lahan gambut di Kalimantan Tengah, masih dianggap sebagai solusi yang paling mudah karena lebih praktis dalam pengaplikasiannya dan respon terhadap OPT lebih cepat. Namun demikian, hal tersebut dikhawatirkan akan memberikan dampak 
negatif terhadap populasi mikrob fungsional tanah. Keberadaan mikrob fungsional tanah menjadi hal yang sangat penting pada lahan-lahan pertanian. Mikroba tanah ini memiliki peranan masing-masing dalam ekosistem terkait dengan aliran energi dan siklus unsur hara sebagai akibat dari aktivitas utama mikrob (pertumbuhan dan perkembangannya).

Pengaruh negatif penggunaan pestisida terhadap populasi mikrob fungsional tanah pada tanah mineral sudah banyak dilaporkan. Busse et al. (2001) mengemukakan bahwa herbisida glyphosate bersifat toksik terhadap bakteri dan cendawan yang diisolasi dari tanah perkebunan Pinus ponderosa, total populasi bakteri heterotrof menurun setelah aplikasi glyphosate. Cycon dan Seget (2007) menyatakan bahwa aplikasi insektisida diazinon, herbisida linuqor dan fungisida mancozeb + dimethomorph merangsang peningkatan populasi mikrob heterotrof pada dosis yang tinggi, meskipun demikian dampak negatif pestisida ditunjukkan pada awal penelitian.

Pada tanah gambut informasi mengenai hal tersebut masih kurang. Tanah gambut, sesuai dengan bahan asal pembentukannya, hampir seluruhnya merupakan bahan organik. Zimdhal (1993) menyatakan bahwa tanah yang mengandung liat dan bahan organik yang tinggi mengadsorpsi pestisida lebih besar dibandingkan tanah berpasir. Oleh karena itu, diduga pengaruh pestisida terhadap aktivitas mikrob fungsional pada tanah gambut tidak seperti yang terjadi pada tanah mineral. Berdasarkan pada latar belakang tersebut, maka penelitian ini bertujuan untuk mengkaji pengaruh penggunaan pestisida terhadap populasi mikrob fungsional tanah pada tanah gambut.

\section{BAHAN DAN METODE}

Waktu dan Lokasi Penelitian. Penelitian dilaksanakan pada bulan Agustus 2014 sampai Mei 2015, di Laboratorium Bioteknologi Tanah dan Laboratorium Kimia dan Kesuburan Tanah, Departemen Ilmu Tanah dan Sumberdaya Lahan, Fakultas Pertanian, Institut Pertanian Bogor. Sampel tanah diambil di lahan gambut yang telah disawahkan yang terletak di Desa Kanamit Jaya, Kecamatan Maliku, Kabupaten Pulang Pisau, Provinsi Kalimantan Tengah. Lokasi pengambilan sampel tanah gambut terletak di sekitar titik geografis $02^{\circ} 55^{\prime}$ '55'LS dan $114^{\circ} 09^{\prime} 44^{\prime \prime}$ BB.

Metode Penelitian. Pengambilan sampel tanah merujuk pada Elsas \& Smalla (1996) dengan menggunakan metode random sampling. Sampel tanah diambil secara komposit dari 10 titik pada hamparan sekitar 1 ha, pada kedalaman $0-25 \mathrm{~cm}$ dari permukaan tanah. Analisis kimia dan fisika tanah awal meliputi $\mathrm{pH}, \mathrm{N}$-total, kadar C-organik, analisis kadar serat, dan tingkat dekomposisi.

Hasil analisis tanah awal (Tabel 1) menunjukkan sampel tanah termasuk dalam kriteria sangat masam dengan nilai $\mathrm{pH} \mathrm{H} 2 \mathrm{O} 3.50$ dan $\mathrm{pH} \mathrm{KCl} \mathrm{3.10.} \mathrm{Lahan}$ gambut umumnya mempunyai tingkat kemasaman yang relatif tinggi dengan kisaran $\mathrm{pH} 3-5$ (Agus \& Subiksa 2008). Kandungan C-organik dan N-total berturut-turut sebesar $52.07 \%$ dan $0.94 \%$, sehingga diperoleh rasio $\mathrm{C} / \mathrm{N}$ yang sangat tinggi yaitu sebesar $55.39 \%$. Analisis kadar serat menunjukkan volume serat 46\%, warna munsell 10 YR 3/1, dan indeks pirofosfat bernilai 2 sehingga berdasarkan kriteria tingkat kematangan gambut menurut Lynn et al. (1974) adalah hemik. Dua jenis pestisida yang diteliti adalah herbisida yang mengandung bahan aktif paraquat dan insektisida yang mengandung bahan aktif buthylphenylmethyle carbamat (BPMC). Kedua pestisida tersebut merupakan jenis pestisida yang umumnya digunakan oleh petani, termasuk para petani di Kalimantan Tengah yang merupakan lokasi pengambilan sampel tanah pada penelitian ini.

Tabel 1 Hasil analisis sifat utama sampel tanah gambut

\begin{tabular}{ll}
\hline \multicolumn{1}{c}{ Sifat fisika kimia tanah } & \multicolumn{2}{c}{ Nilai } \\
\hline $\mathrm{pH}(\mathrm{H} 2 \mathrm{O})$ & 3.50 \\
$\mathrm{pH}(\mathrm{KCl})$ & 3.10 \\
$\mathrm{C}-$ organik (\%) & 52.07 \\
$\mathrm{~N}$-total (\%) & 0.94 \\
$\mathrm{C} / \mathrm{N}$ ratio & 55.39 \\
Volume serat (\%) & 46 \\
Warna munsell & 10 YR 3/1(very dark grey) \\
Tingkat dekomposisi & Hemik \\
\hline
\end{tabular}

Rancangan Penelitian dan Inkubasi. Penelitian ini menggunakan rancangan acak lengkap faktorial (RALF), terdiri dari 2 faktor. Faktor pertama merupakan 7 perlakuan pestisida, yaitu Kontrol (tanpa pestisida), Parakuat $50 \%$, Parakuat $100 \%$, Parakuat $200 \%$, BPMC 50\%, BPMC 100\%, dan BPMC $200 \%$. Faktor kedua adalah 4 waktu inkubasi, yaitu 1, 7, 14, dan 28 hari. Dengan ulangan 3 kali maka diperoleh sebanyak 84 satuan percobaan. Satuan percobaan berupa tanah gambut seberat $500 \mathrm{~g}$ (kering udara) dalam bejana inkubasi. Dosis pestisida yang digunakan disesuaikan dengan anjuran pemakaian yaitu 4 liter ha-1 untuk parakuat dan 1 liter ha ${ }^{-1}$ untuk BPMC, dimana pernyataan perlakuan pestisida 50 , 100 dan $200 \%$ berturut-turut bermakna setengah, satu dan 2 kali dosis anjuran. Penghitungan berat pestisida yang diberikan didasarkan pada kandungan bahan aktif masing-masing pestisida dengan berasumsi 
bulk density tanah gambut sebesar $0.25 \mathrm{~g} \mathrm{~cm}^{-3}$ dan ketebalan gambut terkena pestisida setebal $10 \mathrm{~cm}$. Dengan demikian perlakuan Parakuat 50\%, Parakuat $100 \%$ dan Parakuat 200\% setara dengan pemberian parakuat berturut-turut seberat 552, 1104, dan 2208 $\mu \mathrm{g}$; dan perlakuan BPMC 50\%, BPMC 100\%, dan BPMC $200 \%$ setara dengan pemberian BPMC berturut-turut $242.5,485$, dan $970 \mu \mathrm{g}$, pada masingmasing satuan percobaan. Penetapan waktu inkubasi 1, 7, 14, dan 28 hari berdasarkan Degradation Time (DT50) pestisida merujuk pada Environmental Protection Agency (EPA 1998). Sebanyak 500 g sampel tanah (kering angin) dimasukkan ke dalam bejana inkubasi, ditambahkan $50 \mathrm{ml}$ akuades yang mengandung pestisida sesuai perlakuan, kemudian ditambah lagi akuades sampai mencapai kadar air kapasitas lapang. Inkubasi dilakukan secara terbuka, dan selama masa inkubasi kadar air tanah dipertahankan pada kondisi kapasitas lapang. Bejana inkubasi ditempatkan pada ruangan dengan suhu sekitar $\left(28-30^{\circ} \mathrm{C}\right)$. Setelah setiap waktu inkubasi, tanah pada masing-masing satuan percobaan diambil sebanyak $50 \mathrm{~g}$ untuk penghitungan populasi mikrob fungsional.

Penghitungan Populasi Mikrob Tanah. Penghitungan jumlah populasi mikrob tanah menggunakan dua metode, yaitu metode cawan hitung (plate count) untuk mikrob pelarut fosfat (MPF), mikrob selulolitik, dan Azotobacter; dan metode MPN (most probabel number) untuk Azospirillum. MPF dibiakkan pada media Pikovskaya, mikrob selulolitik pada media Carboxymethyl cellulose (CMC), Azotobacter pada media Nitrogen free manitol (NFM), dan Azospirillum pada media Nitrogen free bromthymol blue (NFB). Inkubasi dilakukan pada suhu $28-30^{\circ} \mathrm{C}$ (suhu ruang) selama congo red $1 \% \pm 15$ menit kemudian dibilas dengan akuades (Hastuti 2007; Rosmimik \& Yuniarti 2007; Santosa 2007). Tingkat pengenceran dan perhitungan populasi mikrob tanah merujuk pada Widyastuti \& Anas (2013). Populasi mikrob pelarut fosfat, mikrob selulolitik dan Azotobacter menggunakan pengenceran $10^{-3}$ dan $10^{-4}$. Azospirillum menggunakan pengenceran $10^{-3}, 10^{-4}$ dan $10^{-5}$. Setelah masa inkubasi dilakukan perhitungan populasi mikrob sehingga didapatkan total populasi (CFU) per gram tanah kering.

Analisis Data. Data yang diperoleh dianalisis dengan menggunakan software SAS (statistical analysis system). Jika terdapat pengaruh signifikan dilakukan uji lanjut Duncan Multiple Range Test (DMRT) pada taraf 5\%.

\section{PEMBAHASAN}

Populasi Mikrob Fungsional Tanah. Hasil penelitian menunjukkan bahwa mikrob fungsional memberikan respon yang berbeda-beda terhadap penggunaan bahan agrokimia, dalam hal ini yaitu aplikasi 2 jenis pestisida: herbisida berbahan aktif paraquat dan insektisida berbahan aktif BPMC (Tabel 2). Adanya kecenderungan populasi Azospirillum yang lebih tinggi dengan pemberian pestisida diduga karena kedua pestisida yang diaplikasikan merupakan pestisida organik, sehingga kelompok bakteri Azospirillum mampu menggunakan karbon ataupun nitrogen yang terkandung di dalam pestisida untuk mendukung kegiatan metabolisme selnya. Insektisida BPMC mengandung gugus karbon sedangkan paraquat mengandung gugus karbon dan nitrogen. Beberapa penelitian menyatakan bahwa pestisida dapat dijadikan sebagai sumber karbon,

Tabel 2 Pengaruh perlakuan pestisida terhadap rata-rata populasi mikrob fungsional tanah selama 28 hari masa inkubasi

\begin{tabular}{|c|c|c|c|c|c|c|}
\hline \multirow{2}{*}{$\begin{array}{c}\text { Perlakuan } \\
\text { pestisida }\end{array}$} & \multicolumn{6}{|c|}{ Populasi mikrob fungsional } \\
\hline & BPF & $\begin{array}{c}\text { Bakteri } \\
\text { selulolitik }\end{array}$ & Azotobacter & Azospirilum & $\mathrm{CPF}$ & $\begin{array}{l}\text { Cendawan } \\
\text { selulolitik }\end{array}$ \\
\hline & \multicolumn{4}{|c|}{$\left(\mathrm{x} 10^{5} \mathrm{CFU} \mathrm{g}^{-1}\right.$ tanah $)$} & \multicolumn{2}{|c|}{$\ldots .\left(\times 10^{4} \mathrm{CFU} \mathrm{g}^{-1} \tan a h\right) \ldots$} \\
\hline Kontrol & $8.80 \pm 0.83 \mathrm{a}$ & $1.22 \pm 1.24 \mathrm{a}$ & $27.10 \pm 0.58 \mathrm{abc}$ & $2.84 \pm 1.68 \mathrm{c}$ & $4.57 \pm 1.07 \mathrm{a}$ & $19.26 \pm 0.28 \mathrm{a}$ \\
\hline Parakuat $50 \%$ & $8.48 \pm 1.73 a$ & $1.67 \pm 0.25 \mathrm{a}$ & $19.56 \pm 0.58 \mathrm{bc}$ & $5.40 \pm 1.90 \mathrm{bc}$ & $4.81 \pm 1.06 \mathrm{a}$ & $14.45 \pm 0.48 \mathrm{a}$ \\
\hline Parakuat $100 \%$ & $5.80 \pm 1.31 \mathrm{a}$ & $1.18 \pm 1.19 \mathrm{a}$ & $14.93 \pm 0.53 \mathrm{c}$ & $6.45 \pm 1.53 \mathrm{ab}$ & $3.16 \pm 0.87 \mathrm{a}$ & $12.64 \pm 0.22 \mathrm{a}$ \\
\hline Parakuat $200 \%$ & $5.57 \pm 1.26 \mathrm{a}$ & $1.06 \pm 0.56 \mathrm{a}$ & $20.21 \pm 0.29 \mathrm{abc}$ & $7.24 \pm 0.47 \mathrm{ab}$ & $5.39 \pm 1.09 \mathrm{a}$ & $19.53 \pm 0.33 \mathrm{a}$ \\
\hline BPMC $50 \%$ & $11.51 \pm 2.09 \mathrm{a}$ & $1.52 \pm 0.26 \mathrm{a}$ & $36.06 \pm 0.38 \mathrm{a}$ & $6.10 \pm 1.38 b c$ & $1.03 \pm 0.94 b$ & $12.39 \pm 0.28 \mathrm{a}$ \\
\hline BPMC $100 \%$ & $6.62 \pm 1.96 \mathrm{a}$ & $0.95 \pm 1.56 \mathrm{a}$ & $34.88 \pm 0.51 \mathrm{ab}$ & $8.89 \pm 0.51 \mathrm{a}$ & $1.65 \pm 1.02 b$ & $11.98 \pm 0.21 \mathrm{a}$ \\
\hline BPMC $200 \%$ & $12.11 \pm 2.06 \mathrm{a}$ & $1.02 \pm 1.58 \mathrm{a}$ & $21.06 \pm 1.63 \mathrm{abc}$ & $7.49 \pm 1.76 \mathrm{a}$ & $5.56 \pm 1.19 b$ & $22.38 \pm 1.27 \mathrm{a}$ \\
\hline
\end{tabular}

Keterangan: CFU = colony forming unit (satuan per koloni); BPF = bakteri pelarut fosfat ; CPF = cendawan pelarut fosfat ; Huruf yang sama pada kolom yang sama menunjukkan pengaruh yang tidak berbeda nyata menurut uji Duncan pada taraf nyata $5 \%$

3-5 hari. Untuk mikrob selulolitik, setelah masa sumber energi dan sumber nutrisi oleh beberapa inkubasi dilakukan flooding dengan menggunakan kelompok mikrob tanah, namun bersifat toksik bagi 
kelompok mikrob lainnya (Bhuyan et al. 1993; Radosevich et al. 1995). Cycon dan Seget (2007) juga menyatakan bahwa penggunaan tiga jenis pestisida (herbisida, insektisida, dan fungisida) secara signifikan merangsang peningkatan populasi bakteri heterotrof. Sebaliknya, kelompok CPF menunjukkan populasi yang lebih rendah dengan perlakuan insektisida BPMC. Cycon dan Seget (2007) dalam penelitiannya mengemukakan bahwa aplikasi insektisida diazinon menurunkan total populasi cendawan sehari setelah pengaplikasian. Aplikasi pestisida dapat menghambat/membunuh kelompok mikrob tertentu namun meningkatkan jumlah kelompok mikrob lainnya dengan membebaskan mereka dari kompetisi (Hussain et al. 2009). mengemukakan bahwa peningkatan populasi bakteri tanah berkaitan dengan waktu biodegradasi dari pestisida yang digunakan. Hal ini mengindikasikan terjadi perubahan kemampuan katabolisme mikrob yang memungkinkan mikrob memiliki kemampuan untuk mendegradasi pestisida dan atau terjadi perubahan kelompok mikrob (Hussain et al. 2009) pada tanah gambut yang telah diaplikasikan pestisida.

Berdasarkan dari hasil uji Anova diketahui bahwa terdapat pengaruh interaksi antara jenis pestisida dengan waktu pengambilan sampel, salah satunya pada populasi bakteri pelarut fosfat (BPF). Tidak ditemukannya koloni BPF pada hari ke-1 setelah aplikasi insektisida BPMC (Tabel 4), diduga berkaitan dengan kemampuan adaptasi BPF yang

Tabel 3 Pengaruh waktu inkubasi terhadap rata-rata populasi mikrob fungsional tanah pada seluruh perlakuan

\begin{tabular}{|c|c|c|c|c|c|c|}
\hline \multirow[b]{2}{*}{ Waktu inkubasi } & \multicolumn{6}{|c|}{ Populasi mikrob fungsional } \\
\hline & $\mathrm{BPF}$ & $\begin{array}{c}\text { Bakteri } \\
\text { selulolitik }\end{array}$ & Azotobacter & Azospirillum & $\mathrm{CPF}$ & $\begin{array}{l}\text { Cendawan } \\
\text { selulolitik }\end{array}$ \\
\hline & \multicolumn{4}{|c|}{ 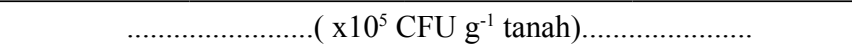 } & \multicolumn{2}{|c|}{.............(x10 $\left.0^{4} \mathrm{CFU} \mathrm{g}^{-1} \tan a h\right) \ldots$} \\
\hline Hari ke- 1 & $3.37 \pm 2.17 \mathrm{c}$ & $0.89 \pm 1.25 \mathrm{~b}$ & $22.85 \pm 0.61 b$ & $5.71 \pm 1.83 \mathrm{ab}$ & $1.23 \pm 0.94 \mathrm{~b}$ & $9.72 \pm 0.24 b$ \\
\hline Hari ke- 7 & $2.42 \pm 1.46 \mathrm{~d}$ & $1.44 \pm 0.31 \mathrm{a}$ & $16.11 \pm 0.64 b$ & $6.17 \pm 1.08 \mathrm{ab}$ & $1.05 \pm 1.09 \mathrm{~b}$ & $12.41 \pm 0.25 b$ \\
\hline Hari ke- 14 & $21.01 \pm 0.57 \mathrm{a}$ & $1.62 \pm 1.29 \mathrm{a}$ & $27.27 \pm 0.50 \mathrm{~b}$ & $4.55 \pm 1.44 \mathrm{~b}$ & $7.18 \pm 0.66 \mathrm{a}$ & $18.57 \pm 0.24 \mathrm{a}$ \\
\hline Hari ke- 28 & $6.85 \pm 1.05 \mathrm{~b}$ & $0.97 \pm 1.24 \mathrm{ab}$ & $33.08 \pm 1.23 \mathrm{a}$ & $8.30 \pm 1.59 \mathrm{a}$ & $5.49 \pm 1.06 \mathrm{a}$ & $23.67 \pm 0.99 \mathrm{a}$ \\
\hline
\end{tabular}

Keterangan : CFU = colony forming unit (satuan per koloni); BPF = bakteri pelarut fosfat ; CPF = cendawan pelarut fosfat ; Huruf yang sama pada kolom yang sama menunjukkan pengaruh yang tidak berbeda nyata menurut uji Duncan pada taraf nyata $5 \%$

Waktu inkubasi (Tabel 3) menunjukkan bahwa aplikasi pestisida umumnya menurunkan populasi mikrob fungsional pada awal perlakuan. Selama masa inkubasi kelompok bakteri fungsional yang diuji menunjukkan populasi yang fluktuatif. Meskipun demikian, keseluruhan populasi mikrob fungsional pada akhir masa inkubasi lebih tinggi dibandingkan awal masa inkubasi. Pada awal aplikasi pestisida, beberapa populasi mikrob akan terpengaruh sehingga populasinya menurun, tetapi setelah periode adaptasi populasi mikrob perlahan-lahan kembali normal bahkan lebih tinggi (Fliessbach \& Mader 2004; Niewiadomska 2004). Tingginya kandungan bahan organik pada tanah gambut, diduga menjadi salah satu faktor yang berperan penting untuk mendukung proses adaptasi mikrob fungsional. Hal ini dikarenakan, ketersediaan bahan organik yang dibutuhkan mikrob fungsional untuk pertumbuhan dan metabolisme terpenuhi. Bahan organik juga ikut mengadsorbsi pestisida yang diaplikasikan, sehingga efek negatif aplikasi pestisida terhadap kelompok mikrob fungsional dapat diminimalkan. Selain itu, kandungan bahan organik yang tinggi pada tanah gambut juga akan meningkatkan laju degradasi pestisida secara biotik atau abiotik (Roger et al. 1994). Rache dan Coats (1998) dalam penelitiannya lebih rendah dibandingkan mikrob fungsional lainnya terhadap perubahan lingkungan. Aplikasi insektisida BPMC, mendorong BPF untuk melakukan dormansi sebagai bentuk adaptasi terhadap kondisi lingkungan yang kurang mendukung pertumbuhannya, kemudian pada hari ke-7 ketika kondisi lingkungan lebih memungkinkan, koloni BPF tumbuh kembali. Hal ini mungkin dikarenakan, pestisida yang diaplikasikan telah mengalami proses degradasi pada hari ke-7. Beberapa kelompok mikrob fungsional tanah selain mampu menyediakan unsur hara, juga mampu menghasilkan zat pengatur tumbuh, dan bertindak sebagai agen biodegradasi senyawa kimia. Pestisida organik yang diberikan ke tanah mungkin digunakan sebagai substrat oleh mikrob tanah dan kemudian melakukan degradasi (Rao 1994) atau BPF mampu memanfaatkan pestisida tersebut sebagai sumber nutrisi. Mikrob berperan dalam peruraian pestisida di dalam tanah, dan atau pestisida yang digunakan dapat dimanfaatkan oleh mikrob sebagai salah satu sumber karbon untuk mendukung aktifitas metabolisme selnya (Rahayuningsih 2009). Wang et al. (2006) menyatakan bahwa aplikasi bahan agrokimia termasuk pestisida menurunkan biomassa mikrob, akan tetapi keanekaragaman kelompok mikrob fungsional meningkat, hal tersebut dikarenakan 
Tabel 4 Pengaruh interaksi jenis pestisida dengan waktu inkubasi terhadap rata-rata populasi bakteri pelarut fosfat

\begin{tabular}{|c|c|c|c|c|}
\hline \multirow{2}{*}{$\begin{array}{l}\text { Perlakuan } \\
\text { pestisida }\end{array}$} & \multicolumn{4}{|c|}{ Interaksi perlakuan pesitisida dan waktu inkubasi } \\
\hline & Hari ke-1 & Hari ke-7 & Hari ke-14 & Hari ke-28 \\
\hline & \multicolumn{4}{|c|}{$\ldots\left(\right.$ x10 $\mathrm{CFU} \mathrm{g}^{-1}$ tanah) } \\
\hline Kontrol & $7.46 \pm 5.86 \mathrm{ab}$ & $2.54 \pm 4.83 \mathrm{abc}$ & $22.95 \pm 5.87 \mathrm{a}$ & $2.25 \pm 5.02 \mathrm{abc}$ \\
\hline Parakuat $50 \%$ & $4.50 \pm 5.64 \mathrm{ab}$ & $0.29 \pm 2.32 \mathrm{de}$ & $24.66 \pm 6.27 \mathrm{a}$ & $4.46 \pm 5.39 \mathrm{ab}$ \\
\hline Parakuat $100 \%$ & $4.10 \pm 5.59 \mathrm{ab}$ & $0.42 \pm 3.37 \mathrm{~cd}$ & $14.65 \pm 5.84 \mathrm{ab}$ & $4.06 \pm 5.44 \mathrm{ab}$ \\
\hline Parakuat $200 \%$ & $7.56 \pm 5.88 \mathrm{ab}$ & $6.80 \pm 5.69 \mathrm{ab}$ & $4.84 \pm 5.55 \mathrm{ab}$ & $3.07 \pm 4.09 \mathrm{ab}$ \\
\hline BPMC $50 \%$ & $0.00 \pm 1.00 \mathrm{e}$ & $2.94 \pm 4.87 \mathrm{ab}$ & $27.46 \pm 6.42 \mathrm{a}$ & $15.66 \pm 5.83 \mathrm{ab}$ \\
\hline BPMC 100\% & $0.00 \pm 1.00 \mathrm{e}$ & $2.10 \pm 5.29 \mathrm{abc}$ & $13.90 \pm 5.96 \mathrm{ab}$ & $10.48 \pm 5.86 \mathrm{ab}$ \\
\hline BPMC 200\% & $0.00 \pm 1.00 \mathrm{e}$ & $1.84 \pm 5.25 \mathrm{bc}$ & $38.63 \pm 6.56 \mathrm{a}$ & $7.96 \pm 5.86 \mathrm{ab}$ \\
\hline
\end{tabular}

beberapa spesies bakteri pada tanah akan mengalami peningkatan populasi pada kondisi stress akibat aplikasi pestisida methamidophos. Johansen et al. (2001) menyatakan bahwa pestisida dapat digunakan sebagai sumber nutrisi dan energi bagi beberapa kelompok mikrob untuk perbanyakan diri, akan tetapi pada kelompok mikrob lain pestisida dapat bersifat sebagai inhibitor atau toksik. Pada penelitian ini, pengaruh negatif pestisida yang digunakan lebih ditunjukkan oleh kelompok BPF, sebaliknya pestisida menstimulasi peningkatan populasi kelompok bakteri Azospirillum. Secara umum populasi mikrob fungsional lebih tinggi terdapat pada aplikasi insektisida BPMC dari pada herbisida paraquat.

Berdasarkan dari hasil penelitian maka dapat disimpulkan bahwa jenis pestisida dan tingkatan dosis pestisida menunjukkan pengaruh yang fluktuatif terhadap populasi kelompok mikrob fungsional. Aplikasi pestisida cenderung menurunkan populasi CPF, tetapi meningkatkan populasi Azospirillum. Pada akhir masa inkubasi populasi mikrob fungsional yang diujikan cenderung lebih tinggi dengan aplikasi pestisida (herbisida paraquat dan insektisida BPMC), meskipun demikian efek negatif pestisida ditunjukkan pada awal masa inkubasi (satu hari setelah aplikasi). Secara umum, herbisida paraquat menunjukkan populasi mikrob fungsional lebih rendah dibandingkan insektisida BPMC. Namun demikian, dibutuhkan penelitian yang lebih mendalam untuk mengkaji seberapa besar pengaruh pestisida khususnya terhadap dua kelompok mikrob fungsional tersebut, terkait dengan potensinya dalam mendegradasi pestisida pada tanah gambut (lahan marginal) yang mengandung bahan organik tinggi.

\section{UCAPAN TERIMA KASIH}

Tim peneliti secara khusus mengucapkan terima kasih kepada pihak BOPTN Institut Pertanin Bogor tahun anggaran 2014yang telah mendanai penelitianini.

\section{DAFTAR PUSTAKA}

Agus F, Subiksa IGM. 2008. Lahan Gambut: Potensi untuk Pertanian dan Aspek Lingkungan. Bogor (ID): Balai Lingkugan Tanah dan World Agroforestry Center (ICRAF). [BBSDLP] Balai Besar Penelitian dan Pengembangan Sumberdaya Lahan Pertanian. 2008. Laporan Tahunan, Konsorsium Penelitian dan Pengmbangan Perubahan Iklim pada Sektor Pertanian. Bogor (ID): Balai Besar Penelitian dan Pengembangan Sumberdaya Lahan Pertanian.

Busse MD, Ratcliff AW, Shestak CJ, Power RF. 2001. Glyphosate toxicity and effect of longterm vegetation control on soil microbial communities. Soil Biol. Biochem. 33: 1777-1789.

Bhuyan S, Sreedharan B, Adhya TK, Sethunathan N. 1993. Enhanced biodegradation of $\gamma$-hexachlorocyclohexane $(\gamma-\mathrm{HCH})$ in $\mathrm{HCH}$ (commercial) acclimatized flooded soil: factors affecting its development and persistence. Pest. Sci. 38: 49-55. Cycon M, Seget ZP. 2007. Effect of selected pesticide on soil microflora involved in organic matter and nitrogen transformation: pot experiment. Pol. J. Ecol. : 207.

Elsas Jd, Smalla K. 1996. Methods for sampling soil microbes. In: Christon JH, Knudsen GR, Melnerney MJ, Stetzenbach LD, Walter MV, editor. Manual of Environmental Microbiologi. Washington D. C: ASM Press. [EPA] Environmental Protection Agency. 1998. Fate, Transport and Transformation Test 
Guidelines. OPPTS 835.1220. Sedimen and Soil and Adsorption/Desorption Isotherm. United State Environmental Protection Agency.

Fliessbach A, Mader P. 2004. Short and long-term effects on soil microorganisms of two potato pesticide spraying sequences with either glufosinate as defoliants. Biol. Fertil. Soils 40:268-276.

HandayantoE,HairiahK. 2007. Biologitanah:Landasan Pengelolaan Tanah Sehat. Malang: PustakaAdipura.

Hastuti RD. 2007. Bakteri penambat nitrogen hidup bebas. Di dalam: Saraswati R, Husen E, Simanugkalit RMD, editor. Metode Analisis Biologi Tanah. Bogor (ID): Balai Besar Penelitian dan Pengembangan Sumberdaya Lahan, Badan Penelitian dan Pengembangan Pertanian, Departemen Pertanian.

Hussain S, Tariq S, Muhammad S, Muhammad A, Azeem K. 2009. Impact of pesticides on soil microbial diversity, enzymes, and biochemical reactions. Elsivier 102: 163.

Johansen K, Jacobsen CS, Torsvik V. 2001. Pesticide effect on bacterial diversity in agricultural soil. Biol. Ferti. Soil. 33: 443-453.

Lynn WC, Mc Kinzie WE, Grossman RB. 1974. Field laboratory test for characterization of histosol. Soil. Sci. Soc. Am. J. 6: 11-20.

NiewiadomskaA. 2004. Effect of carbendazim,imazeta pirand thiramon nitrogenase activity, the number of microorganisms in soil and yield of red clover (Trifolium pretense L). Pol. J. Environ 13, 403-410.

Noor M. 2001. Pertanian Lahan Gambut: Potensi dan Kendala. Jakarta (ID): Penerbit Kanisius.

Rache KD, Coats J. 1998. Comparative biodegradation of organophosphorus insecticides in soil. Specificity of enhanced microbial biodegradation. J. Agric. Food Chem. 36: 193-199.

Radosevich M, Traina SJ, Hao YI, Touvinen OH. 1995. Degradation and mineralization of atrazine by a soil bacteria isolate. Appl. Environ. Microbiol. 61: 297-302.

Rahayuningsih E. 2009 . Analis is Kuantiatif Perilaku Pestisida di Tanah. Yogyakarta: Universitas Gadjah Mada.

Rao S. 1994. Mikroorganisme Tanah dan Pertumbuhan Tanaman. Jakarta (ID): UI-Press.

Roger PA, Simpson I, Oficial R, Ardales S, Jimenez R. 1994. Effect of pesticides on soil and water microflora and mesofauna in wetland ricefields: a summary of current knowledge and extrapolation to temperate environments. Australian J. Experiment. Agric. 34: 1057-1068.

Rosmimik, Yuniarti E. 2007. Mikroba perombak bahan organik. Di dalam: Saraswati R, Husen E, Simanugkalit RMD, editor.
Metode Analisis Biologi Tanah. Bogor (ID): Balai Besar Penelitian dan Pengembangan Sumberdaya Lahan, Badan Penelitian dan Pengembangan Pertanian, Departemen Pertanian. Santosa E. 2007. Mikroba pelarut fosfat. Di dalam: Saraswati R, Husen E, Simanugkalit RMD, editor. Metode Analisis Biologi Tanah. Bogor (ID): Balai Besar Penelitian dan Pengembangan Sumberdaya Lahan, Badan Penelitian dan Pengembangan Pertanian, Departemen Pertanian. Wang MC, Gong M, Zang HB, Hua XM, Yao J, Pang YJ, Yang YH. 2006. Effect of methamidophos and urea application on microbial community level physiology profiles. J. Environ. Sci. Health. 41: 399-413. Widyastuti R, Anas I. 2013. Petunjuk Laboratorium Biologi dalam Praktek. Bogor (ID): Direktorat Jenderal Pendidikan Tinggi, Pusat Antara Universitas Bioteknologi, Institut Pertanian Bogor. Zimdhal RL. 1993. Fundamental of Weed Science. Sandiego (NY): Academia Press. 